\title{
Assessment in the History Classroom
}

Richard Hughes

Illinois State University

Natalie Mendoza

University of Colorado Boulder

The growth of the Scholarship of Teaching and Learning among historians is closely tied to the evolving state of assessment in history classrooms. Just a few years ago James Grossman, the executive director of the American Historical Association, referred to the term assessment as a "remarkably potent" "trigger word" among historians. ${ }^{1}$ Historians have long been skeptical of what Casper and Westhoff recently described as the "assessment regime" in higher education. Yet recent years have brought growing calls from professionals in the discipline, including Grossman, to frame effective teaching as centered on individual and collective efforts to measure student learning of history. ${ }^{2}$ While the origins and specific nature of assessment efforts differ according to settings, historians are increasingly referring to learning outcomes and seeing the value of having historians, rather than administrators or the general public, identify and articulate the nature of meaningful teaching and learning in the history classroom. The emerging Scholarship of Teaching and Learning in History (HistorySoTL) offers unique opportunities to develop discipline-specific assessments that enrich both individual courses and larger curricula.

1 James Grossman and Julia Brookins, “Assessment Is What We Make of It," The Journal of American History 103, no. 4 (2016): 1132-1137.

2 Scott E. Casper and Laura M. Westhoff, "Surprising Opportunities for Historians: Taking Control of the Assessment Process," The Journal of American History 103, no. 4 (2016): 1102-1103.

(C) 2019 Hughes \& Mendoza. Free to copy and share for education and scholarship under a Creative Commons Attribution NonCommercial-NoDerivatives 4.0 License. 
The nature and purpose of assessment has undergone significant changes in recent decades. Older notions of assessment have focused largely on formal summative assessments that measure final learning through exams, research papers, and standardized tests. These summative assessments, long a staple of higher education, often serve the role of an autopsy in that learning is evaluated at the end of the semester, after instruction and student growth is completed. More recent discussions of assessment in secondary and higher education emphasize the importance of effective formative assessments as an integral part of evaluation, and also of the teaching and learning process. Reframing the issue as assessment for learning as it happens rather than the measurement of learning that has already occurred, historians and other instructors are exploring formal and informal ways to assess learning outcomes throughout instruction. According to Dylan Wiliam this process ideally is continual, informative, and motivates "feedback systems."

One example of the application of assessment for learning is the lesson model promoted by the Instructional Skills Workshop (ISW). An intense professional development curriculum created at the University of British Columbia, the ISW model involves lessons that, regardless of discipline or length, require explicit outcomes, a pre-assessment, participatory student learning, and a postassessment. Participants invariably find the ISW workshops to be powerful experiences precisely because formative assessments are central to effective instruction. ${ }^{2}$ The result of the ISW and other efforts has been that assessment moves from the periphery of education to an essential ingredient in decisions about classroom instruction and student learning.

Within the discipline of history, engagement with assessment

\footnotetext{
1 Dylan Wiliam, "What is Assessment for Learning?" Studies in Educational Evaluation 37 (2011): 3-14.

2 Instructional Skills Workshop for Faculty, https://ctlt.ubc.ca/programs/ all-our-programs/instructional-skills-workshop-isw/
} 
(both formative and summative) among instructors has recently shifted toward explicit efforts to measure discipline-specific skills. Research in recent decades suggests a persistent gap between the perceptions and cognitive skills of historians and the approaches of secondary and college students. ${ }^{3}$ As a result, creating and employing assessments that allow historians to effectively measure the discipline-specific skills and concepts necessary for studying history is not only crucial to instruction, it is also central to shaping and defending the precise role of the discipline in larger educational and cultural debates. A basic misunderstanding by the public of what historical study entails and its impact on teaching and learning at the college level are what prompted the History Department at the University of Colorado Boulder (CU) to create the History Teaching and Learning Project (HTLP). HTLP was a two-year endeavor focused primarily on developing department-wide student learning objectives (SLOs) that clearly articulated the discipline-specific skills and concepts students could expect to learn in CU history courses. Significantly, the Scholarship of Teaching and Learning in History was central to this task. After interviewing the faculty and reading their syllabi in order to identify the common ideas in learning goals held across the department, project lead Natalie Mendoza used HistorySoTL to develop a language and coherent organization of what came to be the SLOs. Mendoza also introduced HistorySoTL to the department as a tool for designing and teaching courses and assessing student learning. The HTLP Working Group, for example, was a volunteer group of faculty and grad students that read and discussed HistorySoTL. In the second year of HTLP,

\footnotetext{
3 Richard Hughes, "Encountering History and History Instruction: Perceptions of Emerging Teachers," SoTL Commons Conference: A Conference of Teaching and Learning, Savannah, Georgia, 2019; Sam Wineburg, Historical Thinking and Other Unnatural Acts: Charting the Future of Teaching the Past (Philadelphia, PA: Temple University Press, 2001); Bruce A. VanSledright, The Challenge of Rethinking History Education: On Practices, Theories, and Policy (New York: Routledge Publishing, 2011).
} 
the Working Group paid particular attention to the practice of scholarly teaching: Members approached their teaching as a site of intellectual inquiry and used HistorySoTL to explore a problem in their teaching. This exercise led Working Group members to change their teaching in a range of ways, from clarifying learning goals to developing new active learning strategies to re-evaluating the assessments they currently used in their courses. ${ }^{4}$ As for the rest of the department, the HTLP Workshop \& Discussion events featured HistorySoTL scholars, such as Lendol Calder, David Pace, Leah Shopkow, and Laura Westhoff, who shared their research with faculty and graduate students. These expert guest presentations served as a preface to a workshop period in which the audience discussed how the HistorySoTL research it just learned about could be applied in their own classrooms. After two years of active support and focus, the CU History Department continues the work it began with HTLP-including its reliance on HistorySoTL-to now consider teaching practices and assessments that best align with the SLOs, to re-evaluate its major pathway options and course sequencing, and to cultivate a culture of scholarly teaching that it views as critical to sustaining the important pedagogical gains the department made in the previous two years. ${ }^{5}$ In HTLP, we get a glimpse of how historians can begin to think about assessment, learning objectives, and teaching methods as part of a vertically aligned curriculum. Importantly, this curricular vision extends across a department's course offerings and not just through the individual courses we teach.

\footnotetext{
4 The idea for scholarly teaching in the Working Group was inspired by the collaborative work Mendoza had done with David Pace and Laura Westhoff as members of an ad hoc committee for the American Historical Association on defining HistorySoTL and how the discipline might engage it. The statement that came from that work, "Guidelines for the Incorporation of the Scholarship of Teaching and Learning in the Work of the History Profession," can be found at: https://www.historians.org/jobs-and-professional-development/statementsstandards-and-guidelines-of-the-discipline/guidelines-for-the-incorporation-ofthe-scholarship-of-teaching-and-learning-in-the-work-of-the-history-profession. 5 https://www.colorado.edu/history/history-teaching-and-learning-project.
} 
Efforts such as HTLP in Colorado did not appear very likely only a decade ago. Two articles in the Journal of American History in the last fifteen years serve as a useful barometer for the changing state of assessment among historians over the period. Richard Rothstein's 2004 essay, "We Are Not Ready to Assess History Performance," framed the challenges of assessment largely in terms of curriculum and the negative impact of enduring political and ideological factors. In contrast, a 2016 article by Scott Casper and Laura Westhoff entitled, "Surprising Opportunities for Historians: Taking Control of the Assessment Process," suggested that a new promising climate of assessment had emerged that focused less on intractable curriculum debates than newer efforts to "identify key areas of competency and skill" within the discipline. Indeed, the ability of historians such as those involved with HTLP to articulate a discipline-specific pedagogy and to assess the ability of students to read, think, and communicate like historians has become a powerful avenue in recent years for defending the discipline and, more generally, the liberal arts. ${ }^{6}$

Furthermore, while projects have increasingly embraced assessment as an invaluable instrument to improve classroom instruction, some discussions of assessment among historians

6 Richard Rothstein, "We Are Not Ready to Assess History Performance," The Journal of American History 90, no. 4 (2004): 1381-1391; Casper and Westhoff, 1103. Other examples include Gary Kornblith and Carol Lasser, "Will That Be on the Exam?' The Role of Testing in Teaching and Learning American History," The Journal of American History 90, no. 4 (2004): 1379-1380; Timothy A. Hacsi, "Document-Based Question: What Is the Historical Significance of the Advanced Placement Test?" The Journal of American History 90, no. 4 (2004): 1392-1400; David Pace, "Assessment in History: The Case for 'Decoding' the Discipline," Journal of the Scholarship of Teaching and Learning 11, no. 3 (2011): 107-119; Gary Kroll, Jessamyn Neuhaus, and Wendy Gorden, "Slouching Toward Student-Centered Assessment," The Journal of American History 102, no. 4 (2016): 1108-1122; Jeffrey McClurken and Krystyn Moon, "Making Assessment Work for You," The Journal of American History 102, no. 4 (2016): 1123-1131. See also the seminal work of the Stanford History Education Group, specifically the Beyond the Bubble project and the development of History Assessments of Thinking (HATs), https://sheg.stanford.edu/history-assessments. 
perceive such efforts as only a partial solution. From this perspective, what is needed are innovative assessments that promote a new epistemological architecture for how we teach history - instructional strategies and a larger curriculum that promote and measure students' disciplinary understandings rather than simply the historical content or facts so often assumed to be the primary objective of history education. For these instructors, assessment has evolved further from an attractive teaching tool to part of a larger teaching paradigm that reframes the nature and purpose of the history classroom toward inquiry and the cognitive skills of historians. ${ }^{7}$ Not surprisingly, different priorities in terms of student learning demand different assessments and, whether the focus is improving specific instruction or reconceptualizing the history curriculum, the questions and evidence that drive SoTL research are invaluable for historians as they seek to make better decisions about what goes on in the history classroom.

7 Sam Wineburg, Mark Smith, and Joel Breakstone, "What Is Learned in College History Classes?" The Journal of American History 104, no. 4 (2018): 983-993; Lendol Calder and Tracy Steffes, "Measuring College Learning in History," in Improving Quality in American Higher Education: Learning Outcomes and Assessments for the $21^{\text {st }}$ Century, eds. Richard Arum, Josipa Roksa, and Amanda Cook (San Francisco, CA: Jossey-Bass, 2016), 37-86; Bruce A. VanSledright, Assessing Historical Thinking and Understanding: Innovative Designs for New Standards (New York: Routledge: 2014); Lendol Calder, "Uncoverage: Toward a Signature Pedagogy for the History Survey," The Journal of American History 92, no. 4 (2006): 1358-1370; Joan Middendorf and Leah Shopkow, Overcoming Student Learning Bottlenecks (Sterling, VA: Stylus Publishing, 2017); David Pace, The Decoding the Disciplines Paradigm: Seven Steps to Increased Student Learning (Bloomington, IN: Indiana University Press, 2018); http:// decodingthedisciplines.org/. 